\title{
A Resilience Pattern in Village level: The Case Babalan Village, Pati, Central Java Indonesia
}

\author{
Ragil Nurwahyudi ${ }^{1, *}$, and Maryono Maryono ${ }^{2}$ \\ ${ }^{1}$ Master Program of Environmental Science, School of Postgraduate Studies, Diponegoro University, Semarang-Indonesia \\ ${ }^{2}$ Department of Urban and Regional Planning, Faculty Engineering,, Diponegoro University, Semarang - Indonesia
}

\begin{abstract}
Based on the Indonesia Disaster Prone Index 2013, Pati Regency is a high risk area of disaster and is ranked 11th level Central Java province while nationally ranked 156. Babalan Village located on the edge of Juwana River has disaster history from 2006-2014 shows flood disaster Giving the greatest probability and impact followed by rat pest, tornado, drought, fire. The public recognizes the signs of a continuous flooding of heavy rains accompanied by clouds all over the edge, the continuous rise of the Juwana River surface to overflow, ants, isoptera, and animals out of its nest, "Yuyu Bule", earthworms out, clear water for "Rowo floods ", Brownish water for the flash floods. Most residents have boats and can make rafts from makeshift materials (jerry cans, bamboo, banana stems). Make "Ranggon" at home for those who do not evacuate for a place to stay during the flood. Citizens elevate the kitchen (to evacuate people and goods / household furniture). Breeding Tyto Alba owl for rats pest control post-flood and controllers in the fields. Develop vegetable crops in the yard with viticulture pattern (upstairs) if flood can be moved and can eat vegetables during flood. Have food reserves for stock before outside help comes. Citizens initiate "Water Bath honesty" to meet the water needs during the dry season.
\end{abstract}

\section{Introduction}

According to The Indonesian National Agency for Disaster Management (BNPB), there were 12,494 disasters in the period of 2002-2012 with 190,087 numbers of casualties [1]. The first Pati regency is one of the 35 districts / cities in central java province that are vulnerable to disaster, both caused by natural, nonnatural and human factors. Based on the Indonesia Disaster Risk Index (IRBI) 2013, Pati District is a high risk area of disaster and is ranked 11 th level Central Java province while nationally ranked 156 .

Central Java Province is one of the strategic province in Indonesia, that hold in significant role the perform of energy resilience. From the demand view side, Central Java was dynamic place. Central Java province is also a prone province since many natural hazards hit, such as flood, earthquake, and volcano eruption. One conceptual indicator that can be used to assess energy resilience is the stakeholer's effort to understand energy needs in the event of a disaster [2].

There are several disasters that can happen in Pati Regency. In the rainy season Pati district is an area prone to floods, flash floods, landslides or hurricanes. This is influenced by the geographical condition of Pati Regency which has 93 rivers that are spread evenly throughout the region. In addition Pati Regency also has an area with a slope of more than $40 \%$ and areas prone to landslides are Cluwak District, Gembong, Tlogowungu, Gunungwungkal, Sukolilo, Kayen, Tambakromo, Winong and Pucakwangi [3]. While in the dry season in some areas of Pati Regency also occurs drought disaster.

Disasters have destroyed the results of hard-earned development. Funds used for emergency response and post-disaster recovery have also reduced the budgets that should be utilized for national development and poverty eradication programs. In the event of a disaster, the poor and marginalized who live in vulnerable areas will be the most disadvantaged, since the greatest number of victims usually comes from this group and the impoverishment caused by the disaster will mostly befall them.

Considering the significant impact of natural disaster, it is important to determine the level of disaster risk in a country's area. A deep understanding of the matter will help government to develop a comprehensive framework or policy to minimize the negative impact of disasters. In addition, understanding risk level should also be followed up by the assessment of resilience level toward the disasters. As mentioned by Mayunga [4].

Disaster resilience is the capacity or ability of a community to anticipate, prepare for, respond to, and recover quickly from impacts of disaster. Furthermore, disaster resilience along with economic vitality, environmental quality, social and inter-generational

\footnotetext{
Corresponding author: ragilenvironment@,gmail.com
} 
equity, quality of life, and participatory process are the six principles of sustainability [5].

The behaviour alternation to the less preparedness community to cope disaster may be anticipated by internal mechanism. The lesson learned in Indonesia of disaster countermeasures is dominantly done through external mechanism, i.e., the disaster countermeasures is done by actors coming from outside of the community. So far, the disaster countermeasures in Indonesia were done by extensive intervention by externals actors, while the local communities were only becoming an object of the programs. That external mechanism may create powerless community in the reduction of disaster vulnerability. The external factor did not involve the local community and considering the local potential resources to reduce the disaster risk. Moreover, the community response, it was also expressed by the local leader, of 'nantang perkoro' which mean expecting somewhat bad in the future. According to the community, 'We are now living in safe and peace; we don't have to prepare ourselves for the uncertain coming disaster [6]

The United Nations International Strategy for Disaster Reduction (UNISDR) defined resilience as "the ability of a system, community or society exposed to hazards to resist, absorb, accommodate to and recover from the effects of a hazard in a timely and efficient manner, including through the preservation and restoration of its essential basic structures and functions [7].

In addition, Razafindrabe et al. [8] proposed that there were five dimensions of resilience towards climate disaster, namely physical, social, economic, institutional, and natural (hazard frequency and hazard density). Meanwhile, Cutter et al. [9] proposed indicators of community resilience which included several dimensions, such as ecological, social, economic, institutional, infrastructure and community capacity.

A disaster is a serious disruption in the functioning of a community, which exceeds its capacity to cope within its own resource [10]

In accordance with the disaster management paradigm according to Law number 24 of 2007 that the disaster management paradigm must be integrated and comprehensive preventive with the participation of all parties, both the government of the business community and society.

Babalan Village is part of Gabus Subdistrict Pati Regency with geographical location as follows:

North : Juwana River, Gajah Mati Village and Banjarsari Village

East : Koripandriyo Village

South : Plumbungan Village

West : Tanjang Village

Administratively divided into 3 (three) dukuh, 3 (three) Rukun Warga and 15 (fifteen) Rukun Tetangga (RT). Total area of $235.20 \mathrm{Ha}$ consisting of rice field 161,20 Ha; Not 7.96 Ha of rice fields and nonagricultural land of $66.36 \mathrm{Ha}$ with the type of land of Babalan village is alluvial (clay). Babalan Village through 3 (three) rivers are 1 (one) big river (Juwana river) and 2 medium river. Babalan village area belongs to a group of areas with a height of 0-8 meters above sea level [11]. This condition causes brackish conditions during the dry season, as sea water rises through the Juwana River.

History of disaster events in Babalan village from the last 9 (nine) years 2006 to 2014, the most frequent occurrence of natural disasters due to floods that occur almost every year, droughts, high winds and catastrophic crop failures due to rat pests [12]. Disaster management is a systematic and comprehensive effort to tackle all disaster events quickly, accurately and accurately to reduce victims and losses [3].

Article 3 of Law No. 24 of 2007 on Disaster Management states that disaster management is based on the principles of: humanity, justice, equality of positions in law and government, balance and harmony, law and order of law, togetherness, environmental sustainability, science and technology. In addition, disaster management should also be based on the following practical principles: fast and precise, prioritized, coordinated and integrated, effective and effective, transparency and accountability, partnership, empowerment, non-discrimination and non-prosecution [13].

Sustainable development of the flood plains is one of the crucial development concerns around the world. Theoretically, sustainable development can be seen as a process of positive biophysical and socio-economic change or creating wealth (capital) that meets the needs of present generation and can be continued indefinitely without diminishing the natural systems upon which it depends or excluding the range of opportunities available to future generations. This is a continuous adaptation process to evolving environmental, economic, and social systems $[14,15]$.

Community in the context of disaster management is a group that may share one or more things in common, such as living in the same environment, having similar disaster risk exposure, or having been affected by a disaster [16].

A similar definition, though more closely related to the built environment, is proposed by Ginige [17-11] and Amaratunga [18]. They define community as individuals and groups sharing a natural and built environment that is vulnerable to hazards. In other words, community is the general public; the users and occupants of the built environment and the beneficiaries of post-disaster reconstruction.

Boughton explained that community, environment, and hazard are element of risk. The risk itself is a result of interaction between hazard that may create damage and lost, community that may be affected, and the specific situation of environment which may reduce the level of hazard [19].

Risk assessment is based on a review of both technical features of hazards such as location, intensity, frequency and probability; And also an analysis of the physical, social, economic and environmental dimensions of the vulnerability and vulnerability of Exposure, while taking account of the handling capabilities associated with the Vulnerability Risk Scenario measures the physical, social, economic, and 
environmental conditions or processes that increase the vulnerability of a community For hazard impact [20].

Disasters can erase the benefits of development investments, and poorly planned development interventions may become a source of hazard. Therefore, disaster planning is a necessary step and is needed to realize the MDGs and sustainable development. These are elements of a consensus that was reaffirmed at the World Conference on Disaster Reduction (WCDR) in Kobe, Japan, on 18-22 January 2005. Also at that meeting climate change was recognized as posing an immediate and long-term threat to the achievement of the MDGs and sustainable human development, and, as such, should be an integral part of disaster planning [21].

\section{Method}

Qualitative method is a research procedure that will produce qualitative data in the form of written or oral words of the people and an observed process. This type of research is a problem-solving procedure that is investigated by describing the state of the subject / object of research (community, a process and others) at the present moment based on facts that appear or as is [22].

\section{Result and Discussions}

\subsection{Risk Identification}

Risk identification and Assessment are usually performed by key actors at the national, provincial, district, districts and village levels [23].

The focus of disaster management is to reduce the risk posed by actual and potential hazards [24]. The capacity of a system, community or society to resist or to change in order that it may obtain an acceptable level in functioning and structure. This is determined by the degree to which the social system is capable of organizing itself and the ability to increase its capacity for learning and adaptation, including the capacity to recover from a disaster [25].

What needs to be done before estimating flood warning standards is to understand the risks of a flood disaster. The following things need to be done to determine the level of Risk of a region to flash flood disaster.

1. Identification of disaster areas based on flood prone maps;

2. Conduct a survey of infrastructure in vulnerable areas including the following:

- Residential location;

- Flood retaining buildings;

- Flood detection infrastructure.

3. Conduct a survey on the social conditions of the community including:

- Population by gender, age, illness sickness, occupation, education level, wealth, family members;
- Knowledge of the causes and processes of disasters; - disaster preparedness.

4. Conduct analysis through the survey results data above to determine the level of risk of a region;

5. Conduct standard warning forecasts

Data The last nine years from 2006 to 2014 disaster occurrence in Babalan village, natural factor is Flood almost happened every year, Drought and Wind fast while non natural factor is Failed Harvest due to Rat Attack. Floods occur in 2006, 2008, 2009, 2010, 2011 and 2014. Pest attacks in 2012 and 2013. Strong winds occur in 2014 and drought in 2006.

From the above data it can be seen that the disaster that ever happened in Babalan Village is Flood, Drought and Wind, then it is estimated that probability is scored by category:

1. Score 5 Definitely (almost certainly $80-99 \%$ ).

2. Score 4 Most likely (60-80\% occur next year, or once in the next 10 years)

3. Score 3 Possible occurrence $(40-60 \%$ occur next year, or once in 100 years)

4. Score 2 Small Possibilities ( $20-40 \%$ in 100 years)

5. Score 1 Possibly small (up to $20 \%$ )

If the above probability is supplemented by the estimated impact if the disaster does occur with consideration of the impact factors such as:

1. the number of victims;

2. Loss of property;

3. Damage to infrastructure and facilities;

4. The wide range of affected areas; and

5. Socio-economic impacts.

Even this impact is given weight as follows:

1. Score 5 Very Severe $(80 \%-99 \%$ devastated and total paralyzed area)

2. Score 4 Severe $(60-80 \%$ of the area destroyed)

3. Score 3 Medium ( $40-60 \%$ of affected area is damaged)

4. Score 2 Lightweight (20 - $40 \%$ of damaged area)

5. Score 1 Very Light (less than $20 \%$ broken area)

It is estimated that the scores obtained are as follows (figure 1)

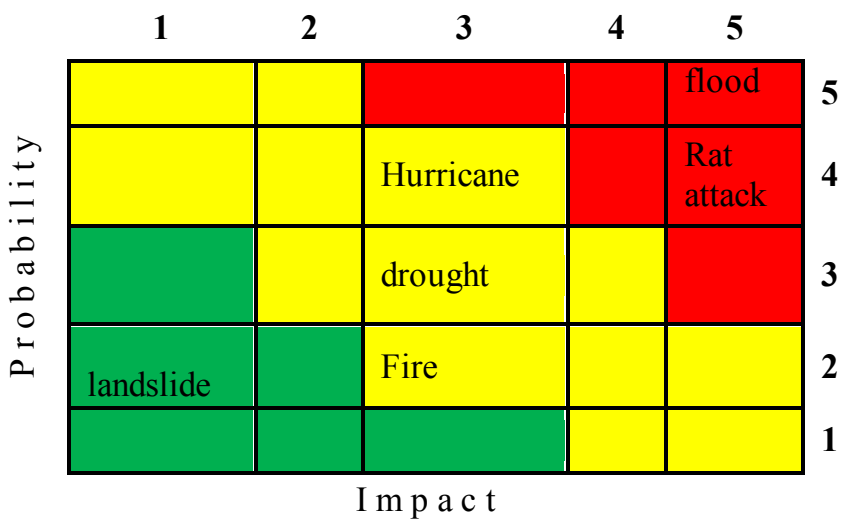

Fig. 1. Disaster Risk Assessment 
Table 1. Results of the Focus Discussion Group (FGD) together with community representatives

\begin{tabular}{|c|c|c|c|c|}
\hline \multirow{2}{*}{ Character } & \multirow{2}{*}{ Character Details } & \multirow{2}{*}{ Threat Profile } & \multicolumn{2}{|c|}{ Risk } \\
\hline & & & $\begin{array}{l}\text { Individual / } \\
\text { Family }\end{array}$ & $\begin{array}{c}\text { Community / } \\
\text { Village }\end{array}$ \\
\hline Cause (origin) & $\begin{array}{l}\text { Heavy rains, the Juwana River Flood and } \\
\text { the Sani river }\end{array}$ & \multirow{10}{*}{$\begin{array}{c}\text { Starting from } \\
\text { continuous cloudy } \\
\text { rain, while the river } \\
\text { Juwana experiencing } \\
\text { a continuous increase, } \\
\text { eventually } \\
\text { overflowing, water } \\
\text { inundated rice fields, } \\
\text { roads, settlements } \\
\text { with high puddle } 0.5 \mathrm{~s} \\
\text { / d } 3 \text { m long puddle of } \\
\text { one week to } 4 \text { months } \\
\text { resulting in physical } \\
\text { damage and } \\
\text { environment and loss } \\
\text { of property: } \\
\text { Population displaced, } \\
\text { disease epidemic: } \\
\text { Diarrhea, Skin } \\
\text { Disease, Coughs } \\
\text { Cold, Fever and } \\
\text { Muntaber. Rice fields } \\
\text { failed to harvest, } \\
\text { damaged roads and } \\
\text { people stopped their } \\
\text { activities in earning a } \\
\text { living }\end{array}$} & & \\
\hline Destructive Power & $\begin{array}{l}\text { Long standing puddles for rowo floods, } \\
\text { mud and strong currents for flash floods }\end{array}$ & & \multirow{9}{*}{$\begin{array}{l}\text { Food shortages, } \\
\text { Decreased health } \\
\text { conditions, } \\
\text { outbreaks of } \\
\text { disease, can not } \\
\text { work, crop } \\
\text { failure, } \\
\text { Livestock loss / } \\
\text { loss, damage / } \\
\text { loss of furniture, } \\
\text { damage to } \\
\text { homes, } \\
\text { displacement }\end{array}$} & \multirow{9}{*}{$\begin{array}{c}\text { Cessation of } \\
\text { village } \\
\text { government } \\
\text { services, road } \\
\text { damage, } \\
\text { cessation of } \\
\text { community } \\
\text { processes, } \\
\text { public facilities } \\
\text { can not be used }\end{array}$} \\
\hline Warning \& Signs & $\begin{array}{l}\text { Continuous heavy rain accompanied by } \\
\text { clouds all over the edge, the rise of the } \\
\text { surface of the river Juwana continuously to } \\
\text { overflow, Ants, terminet, and animals out of } \\
\text { the nest, crab (Parathelphusa convexa) } \\
\text { called "Yuyu Bule", Earthworms out, clear } \\
\text { water for the old flood "rowo flood", } \\
\text { brownish water for flash flood }\end{array}$ & & & \\
\hline Interrupted Time & Fast and Slow & & & \\
\hline Speed is present & Fast and slow & & & \\
\hline Frequency & $\begin{array}{l}\text { Flood often almost every year (dukuh Gilis } \\
\text { area) big flood 3-5 years (whole village) }\end{array}$ & & & \\
\hline Genesis Period & December to March & & & \\
\hline Duration & $\begin{array}{l}\text { Mountain or flash flood from Sani river 1 } \\
\text { week, "rowo" flood from Juwana river 3-4 } \\
\text { months }\end{array}$ & & & \\
\hline Intensity & $\begin{array}{l}\text { Flooding is in Gilis Hamlet area of the } \\
\text { entire flood of villages }\end{array}$ & & & \\
\hline $\begin{array}{l}\text { Position of the } \\
\text { source of the } \\
\text { threat }\end{array}$ & Juwana River and Sani River in the village & & & \\
\hline
\end{tabular}

Types of hazard threats that need to be addressed. Threat assessed danger level by scale (3-1):

1. High danger / threat value 3 (red) is flood and mouse attack.

2. Danger / threat is the value of 2 (yellow) is a hurricane, drought and fire

3. Danger / low threat value 1 (green) is landslide From the results of the Focus Discussion Group (FGD) together with representatives of the community elements of the disaster picture of Babalan Village in Table 1.

The pattern of resilience of the Babalan villagers is:

1. Recognizing the signs of the coming of continuous heavy floods of rain accompanied by cloudy throughout the tip, the rising surface of the river Juwana continuously to overflow, Ants, larons, and animals out of the nest, Parathelphusa convexa called "Yuyu bule", Earthworms out, clear water to "flood rowo", Brownish water for Flash floods.

2. There is a model of giving information to the residents about the flood (SMS, Mosque Speaker, etc.)

3. Can make a raft of makeshift materials (jerry cans, bamboo, banana stems, etc.)

4. Make "ranggon" at home for those who do not evacuate. Ranggon is a place of survival when flooding in a house made of wood or bamboo.

5. The average citizen has a boat (each house / head family).
6. Average citizens have raised the kitchen (to evacuate people and goods / household furniture).

7. Breeding Tyto Alba owl for rat pest control (Fig. 2)

8. Develop vegetable crops in yard with verticulture pattern (upstairs) if flood can be moved and can eat vegetables during flood.

9. Have food reserves for stock before outside help comes.

10. Initiate "Water Bath of Honesty" in managing the provision of clean water.

11. Make a flood map of the village in a simple way (Fig. 3).

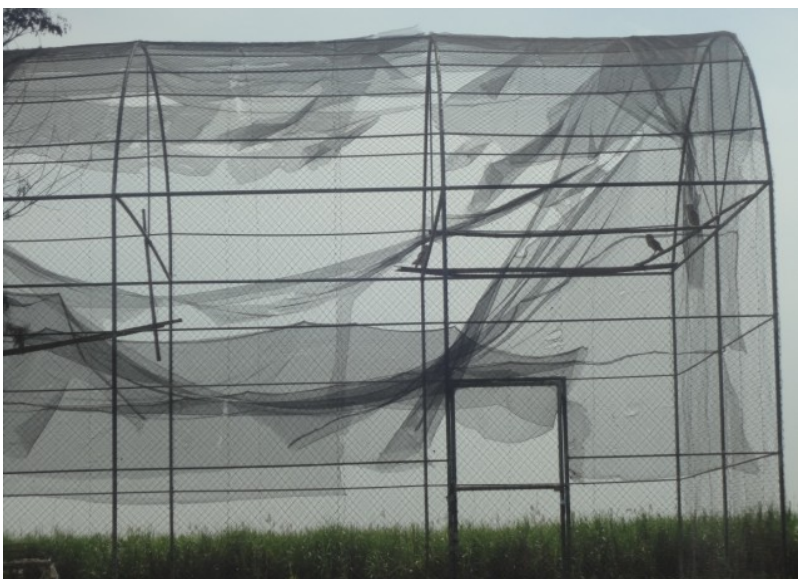

Fig. 2. Captive breeding of Tyto Alba in Babalan Village, Pati, Central Java 


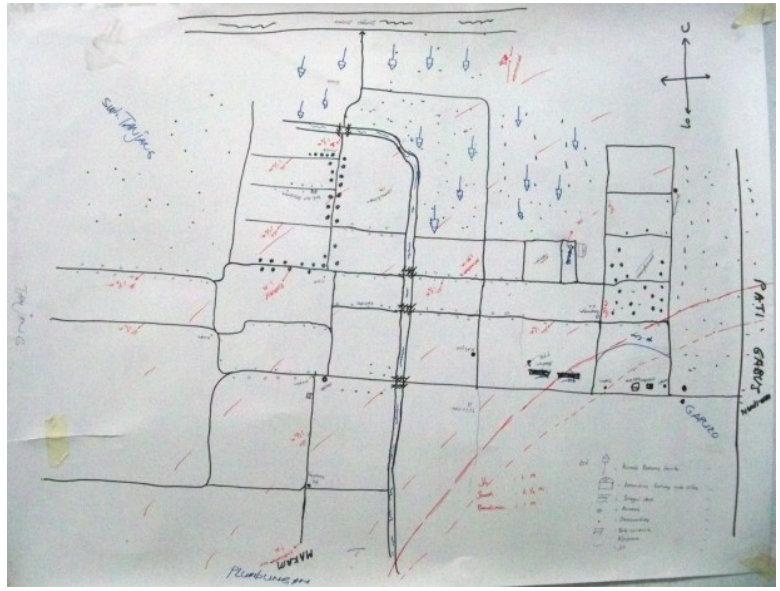

Fig. 3. Map of Flood Directions by Babalan village people

\subsection{Early warning system}

One must also juxtapose 'top down' disaster management in both MDCs and LDCs with the selfprotection efforts made by households and communities them selves actions based on local knowledge and the activities of the institutions of civil society that work on natural and technological hazards from 'the bottom up' [26]. Moreover this study also showing the stakeholder intention in preparedness, at which have been discuss for disaster waste management [27]

In addition to EWS tools, early warning systems implemented by the Babalan villagers are (Fig.4) :

Symptom Observation:

Continuous heavy rain accompanied by clouds all over the edge, continuous rise of the Juwana surface, Ants, termite, and animals coming out of its nest, "Yuyu bule", Earthworms out, clear water for "rowo" flood, brownish water for flash floods.

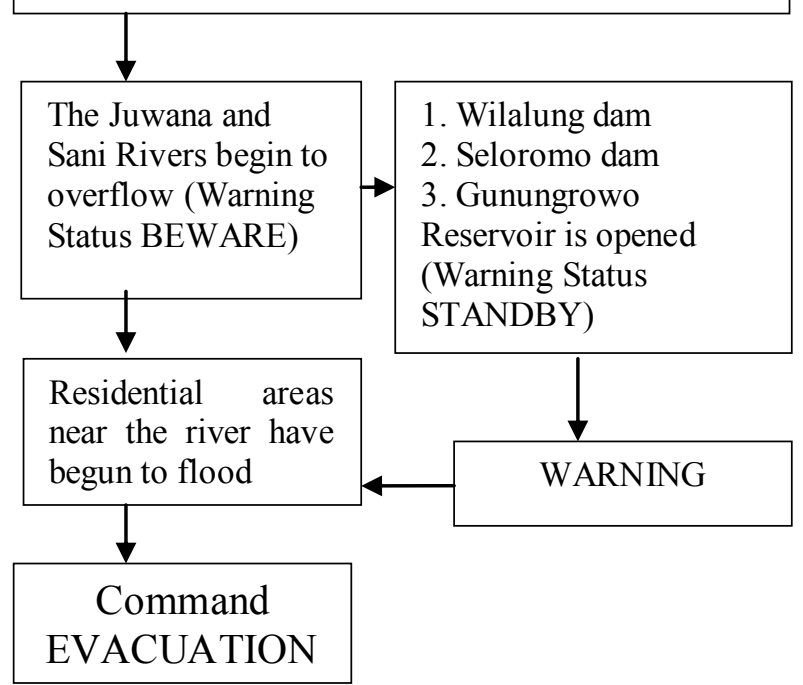

Fig. 4. Forecast Method Standard Warning in Babalan village

\section{Conclusion}

The robustness pattern of a resilient village in Babalan Village can prepare people living in disaster prone areas. Babalan Village Community is now able to identify safe areas and create evacuation routes. It is also shown that stakeholder have been intention to

\section{References}

1. BNPB, Data dan informasi bencana Indonesia (data and information of disaster in Indonesia), Retrieved from: 〈www.dibi.bnpb.go.id〉. 2013

2. Maryono et al. Procedia - Social and Behavioral Sciences 227, 146 - 151( 2016 )

3. Peraturan daerah kabupaten pati nomor 5 tahun 2011 tentang Rencana Tata Ruang Wilayah Kabupaten Pati tahun 2010-2030

4. J.S. Mayunga, Understanding and applying the concept of community disaster resilience: a capitalbased approach, A draft working paper prepared for the summer academy for social vulnerability and resilience building, Munich, Germany, 22-28 July (2007).

5. [5-16]Natural Hazards Center (University of Colorado) Holistic Disaster Recovery: Ideas for Building Local Sustainability After a Natural Disaster Natural Hazards Center, Boulder, Colorado (2006)

6. S. Maarif, et.all. Indonesian Journal of Geography, Vol. 44, No. 2, December 2012 : 173 - 182

7. UNISDR. Terminology, Retrieved from: 〈http://www.unisdr.org/we/inform/terminolo gy , 2012 (accessed on 30.06.12).

8. B.H.N. Razafindrabe, G.A. Parvin, A. Surjan, Y. Takeuchi, R. Shaw, J. Environ. Disaster Manag., pp. 101-116.1 (2009).

9. S.L. Cutter, L. Barnes, M. Berry, C. Burton, E. Evans, E. Tate, J. Webb. Glob. Environ. Change, pp. 598-606 18 (2008),

10. Bradley, D.T., MacFarland, M., Clarke, M., The effectiveness of disaster risk communication: A systematic review of intervention studies. http://www.ncbi.nlm.nih.gov/pubmed/25642365 (2014)

11. Yayasan Sheep Indonesia. Benang Kusust Daerah Aliran Sungai Juwana. Yayasan Sheep Indonesia: Yogyakarta. (2010)

12. BPBD. Rencana-rencana Penanggulangan Bencana. 2014

13. Nurjanah,dkk.. Manajemen Bencana. Bandung: ALFABETA. (2012)

14. [14-10] B. Dalal-Clayton, B. Sadler. Sustainability appraisal: a sourcebook and referenceguide to international experience. Routledge. (2014)

15. [15-20].B. Sadler, On evaluating the success of EIA and SEA. Assessing impact:Handbook of EIA and SEA follow-up 248-285.(2004)

16. [16-1].I. Abarquez, and Z. Murshed, Communitybased Disaster Risk Management: A Field 
Practioners' Handbook, ADPC, Pathum Thani. (2004)

17. [17-11]K. Ginige, and D. Amaratunga, "Capacity development for post-disaster reconstruction of the built environment", in D. Amaratunga, and Haigh, R.P. (Eds), Post-disaster Reconstruction of the Built Environment: Rebuilding for Resilience, Wiley, Chichester, pp. 13-29. (2011)

18. [18-3]. D. Amaratunga, and R.P. Haigh, "Introduction", in D. Amaratunga, and R.P. Haigh, (Eds), Post-disaster Reconstruction of the Built Environment: Rebuilding for Resilience, Wiley, Chichester, pp. 1-12. (2011)

19. [19-6] Boughton, G. the community: central to emergency risk management in The Australian Journal of Emergency Management, 13(2): 2-5 (1998),

20. [20] Ramli, Soehatman. Pedoman Praktis Manajemen Bencana, Dian Rakyat; Jakarta. (2010)
21. [21-24]. UN/ISDR World Conference on Disaster Reduction Kobe, 18-22 January 2005. http://www.unisdr. org/. (2005)

22. [22-15] Moleong, Lexy. Metodologi Penelitian Kualitatif. Bandung: PT. remaja Rosdakarya. 2002

23. [23-14].Moe, Tun Lin and Pairote Pathranarakul. An International Journal, Vol. 15 Iss 3 pp. $396-$ 413(2006).

24. [24-2]. D. Alexander, Principles of Emergency Planning and Management. Terra Publishing, Harpenden. (2002b)

25. [25-23] [25-23]..UN/ISDR, Preliminary version prepared as an interagency effort coordinated by the ISDR Secretariat, Geneva. (2002)

26. [26-9]. T. Cannon, Vulnerability Analysis and Disasters'. In D. Parker (ed.) Floods. Routledge, London. pp. 43-55. (2000)

27. Maryono, H. Nakayama, \& T. Shimaoka, Memoirs of the Faculty of Engineering, Kyushu University, 74(3), PP. 79-98 (2015) 